\title{
Three further ways that the COVID-19 pandemic will affect health outcomes
}

\author{
Johnathan Watkins ${ }^{1}$ (i) $\cdot$ Wahyu Wulaningsih ${ }^{1,2}$
}

Received: 15 April 2020/Revised: 15 April 2020/Accepted: 27 April 2020/Published online: 5 May 2020

(C) Swiss School of Public Health (SSPH+) 2020

The COVID-19 pandemic represents an unprecedented challenge. Policy makers, the medical and research community, as well as the wider public have rightly focussed on the deaths caused by the virus. However, we believe there are three further ways in which this pandemic will affect mortality rates around the world.

First, there is the likely mortality rise during the pandemic as health system resources are diverted to helping COVID-19 patients. Interruptions to planned care (e.g. for cancer) and even to non-elective care are likely to cause a modest but significant spike in non-COVID-19-related deaths. For example, one study showed that most head and neck cancers double in size within 1-3 months (Jensen et al. 2007). Delays to screening or management are likely to generate a much higher caseload of late-stage disease.

Second, there is the effect of the ensuing recession, characterised by potentially record levels of unemployment in many countries. In general, health outcomes improve during recessions, mostly driven by fewer cardiovascularrelated deaths possibly as a result of more active lifestyles (Strumpf et al. 2017). On the other hand, some disease outcomes worsen, such as suicides (Reeves et al. 2012) and treatable cancers in countries without universal health coverage (Maruthappu et al. 2016). In this recession though, the pandemic-enforced home isolation could mean that the aforementioned cardiovascular benefits do not materialise, leading to a net rise in mortality rates.

Finally, there is the consequence of the economic response. If countries respond with austerity measures that

Johnathan Watkins

jwatkins@pilar.org.uk

Wahyu Wulaningsih

wahyu.wulaningsih@uhs.nhs.uk

1 PILAR Research and Education, International House, 24 Holborn Viaduct, London EC1A 2BN, UK

2 University Hospital Southampton NHS Foundation Trust, Southampton, UK lead to a real-terms decline in public health and social care spending, we could see hundreds of thousands of 'excess' deaths or more. Our work and that of others have shown that reducing spending without gains in health system efficiency is associated with poor outcomes across all disease areas (Watkins et al. 2017).

To mitigate the negative effects of the first and second points, governments should start defining strategies on when and how to safely exit from lockdown measures as soon as possible. Health system capacity along with the number of new cases and hospitalisations over time, and the emergence of new pharmaceutical interventions are critical inputs to an exit strategy. There are at least three benefits to making plans for an exit strategy now. First, it returns focus on the system capacity measures and pharmaceutical interventions that can save lives independent of non-pharmaceutical demand management measures. Second, it gives visibility to government departments and other organisations on what needs to be put into place for a successful recovery once measures are lifted. Finally, it generates public confidence in policy makers possibly improving adherence to ongoing demand management measures.

To address the economic response challenge, governments need to be prepared to maintain health and care spending in line with demand. Avoiding austerity through increased borrowing or reallocating of budgets is merely a couple of the mechanisms by which such spending objectives could be achieved.

In summary, therefore, the number of lives lost due to COVID-19 has the potential to be dwarfed by the number of lives lost as a result of these three knock-on effects of the pandemic. Governments can prevent or mitigate this effect by: (1) planning and communicating an exit strategy early to avoid needlessly protracted lockdowns and/or illprepared exits and (2) seeking to maintain public health and social care spending levels. 


\section{Compliance with ethical standards}

Conflict of interest The authors declare no conflicts of interest.

\section{References}

Jensen AR, Nellemann HM, Overgaard J (2007) Tumor progression in waiting time for radiotherapy in head and neck cancer. Radiother Oncol 84:5-10. https://doi.org/10.1016/j.radonc.2007. 04.001

Maruthappu M, Watkins J, Noor AM et al (2016) Economic downturns, universal health coverage, and cancer mortality in high-income and middle-income countries, 1990-2010: a longitudinal analysis. The Lancet 6736:1-12. https://doi.org/10.1016/ S0140-6736(16)00577-8
Reeves A, Stuckler D, McKee M et al (2012) Increase in state suicide rates in the USA during economic recession. The Lancet 380:1813-1814

Strumpf EC, Charters TJ, Harper S, Nandi A (2017) Did the Great Recession affect mortality rates in the metropolitan United States? Effects on mortality by age, gender and cause of death. Soc Sci Med 189:11-16. https://doi.org/10.1016/j.socscimed. 2017.07.016

Watkins J, Wulaningsih W, da Zhou C et al (2017) Effects of health and social care spending constraints on mortality in England: a time trend analysis. BMJ Open 7:e017722. https://doi.org/10. 1136/bmjopen-2017-017722

Publisher's Note Springer Nature remains neutral with regard to jurisdictional claims in published maps and institutional affiliations. 